\title{
The Mining Operations and Metallurgy of the Romans in England and Wales, Being the Opening Address of the Historical Section at the Shrewsbury Meeting
}

the Rev. J. Charles Cox LL.D., F.S.A.

To cite this article: the Rev. J. Charles Cox LL.D., F.S.A. (1895) The Mining Operations and Metallurgy of the Romans in England and Wales, Being the Opening Address of the Historical Section at the Shrewsbury Meeting, Archaeological Journal, 52:1, 25-42, DOI: 10.1080/00665983.1895.10852659

To link to this article: http://dx.doi.org/10.1080/00665983.1895.10852659

曲 Published online: 16 Jul 2014.

Submit your article to this journal ๘

Џll Article views: 3

Q View related articles $\square$ 
THE MINING OPERATIONS AND METALLURGY OF THE ROMANS IN ENGLAND AND WALES, BEING THE OPENING ADDRESS OF THE HISTORICAL SECTION AT THE SHREWSBURY MEETING. ${ }^{\mathrm{I}}$

By the Rev. J. CHARLES COX, LI.D., F.S.A.

Irrespective of the occasional and long buried architectural or military remains of Roman occupation, the two most obvious marks of their prowess, which the conquerors stamped upon the provinces and districts they subdued, were the proofs of their skill in (1) road making, and in (2) mining. This has more than once been pointed out by others than the quasi-professional antiquary. The late Mr. Warrington Smyth says:-- "Among the various ways adopted by the Romans for augmenting the commerce of their settlements there are two, of which the traces still remain, the improvement in communication by the laying out of good roads, and the development of the mineral wealth of a country by mining; and since authenticated remains of the latter are very rare in this country, it becomes important to examine with care whatever is attributed to the agency of that great people, and to compare it with their known works in other parts of the world."

To this mar be added the opinion of a yet more eminent man, the late Dr. Phillips, who was president of the Geological Society, and Reader in Geology in the University of Oxford. "I presume," he says, "to think that without full attention to the mining history of Britain, as indicated by fragments in classic authors, and illustrated by processes not yet extinct, and discoveries made from time to time, the opinion which may be formed of the

\footnotetext{
1 Read at the Music Hull, July 27th, 1894. This address has undergone some slight revision and addition since it was delivered, Dr. Cox having arailed himself of information and corrections that were offered by Lord Dillon, Sir Henry Howorth, Chancellor Ferguson,
}

Mr. Waldron, Mr. Fox and others during the interesting discussion that followed the reading of the paper.

-Warrington Smyth's MTemoirs of the Geological Survey of Great Britain, rol. i., p. 480. 
ancient British people would be altogether conjectural, derogatory, and erroneous."

It is simply proposed on the present occasion to endeavour to present a general survey of the question of Roman mining operations among us, availing myself of the labours of others in the past in the same direction, such as the essays of the late Messrs. Thomas Wright, James Yates, John Phillips, Albert Way, and John Taylor, ${ }^{2}$ together with the record of discoveries of much more recent date, and contributing some small amount of original research, particularly in my own county of Derby.

The more the mining operations of the Romans in Britain are considered, and the more the facts and discoveries pertaining thereto are collected together, the more clearly is it demonstrated that their work in this respect was characterised by the painstaking thoroughness and the wisdom which were the usual elements of Roman rule. The ancient inhabitants whom they subdued had already attained to some proficiency in the elements of mining and still more in the working of metals, but under the Romans the mines of Britain were marvellously and generally developed, and maintained in working order throughout the whole of their occupation. It seems tolerably certain that Britain was the most productive mineral territory held by the Romans (with the solitary exception of Spain), and to the prosecution of mining and metallurgy our conquerors applied far greater energy than to any other branch of industry. If it is asked what special motive, in addition to the prevailing ideas of love of power and greed of annexation (which are ever the temptation of big empires), induced the Romans to subdue distant Britain, and to retain it so long within their grasp, the answer is not far to seek. There can hardly be any doubt that the chief inducement was the knowledge of the mineral wealth of Britain-lead, tin, copper, silver, gold,

${ }^{1}$ Proceedings of the Forkshire Philosophical Society, March, 1848.

${ }^{2}$ Wright's Wanderings of an Anti. quary (1854), and Roman Mining Operations in Shropshire and North Wales, Intelleetual Observer (1862). Yates' On the Mining Operations of the
Romans in Britain (Somersetshire Arch. Soc. 1858). Phillips' Ancient Metallurgy in Britain (Arch. Journal, 1859). Way's Relics of Roman Metallurgy (Arch. Journal 1859 or 1865). 'Taplor' Archaology of the Coal Trade (Proc. of Arch. Institute, 1852). 
and iron. It was this that caused the Romans so speedily to penetrate to and to establish themselves in districts so remote from the sea-board as the Peak of Derbyshire (the very navel of England) and the borders of Wales. ${ }^{1}$

Tin, the plumbum album of Pliny (to distinguish it from plumbum nigrum or lead) had been exported in great quantities from Britain long before the Roman invasion. That it came from Cornwall is a certainty, as it is found in no other county. Cornwall, in the opinion of Dr. Phillips (and he gives excellent reasons for his supposition), "chiefly, if not wholly, supplied the tin which entered so many ways into the comforts and necessities, during peace and war, of all the nations surrounding the Mediterranean and Euxine, Baltic and German Ocean; in fact, the world, as distinctly known to the Roman geographers." The discovery of a number of Roman coins among the tin workings of Cornwall seems to be a proot of their continuous presence in this rich mineral district, which was doubtless speedily under their control. Mr. Yates considers that there is sufficient reason to believe that the Emperor had Roman soldiers stationed at the Cornish mines to superintend the working, and to transport the tin to the seat of the empire. But few traces have been found of early blocks or pigs of tin. A remarkable specimen of a double pig of tin, about $3 \mathrm{ft}$. long by $1 \mathrm{ft}$. wide, was dredged up in Falmouth harbour at the beginning of the century, and is now in the museum at Truro. Another portion of a pointed ingot or pig of tin, found in the parish of Mawgan-in-Pyder, is in the same museum. Both of these are figured in the Journal of our Institute for 1859. A rude smelted block of tin, supplied by Mr. G. N. Simmons, found in Ladock, near Truro, and supposed to have been smelted when the Phœnicians traded to Cornwall for tin," formed part of the mineralproduct exhibits of the Great Exhibition of 1851. The tin ore first obtained would, almost of necessity, be that which is called "stream" tin, and it is not a little remarkable to note the accuracy of Pliny's description : "It is a sand, of a black colour, found on the surface of exıgua est copia" (B.G., v., 12). 
the earth, and is only to be detected by its weight. Small pebbles occur along with it, especially in the dry courses of torrents. The miners wash these sands and smelt what subsides in furnaces." $M$ Mr. Yates believes that the chief use of Cornish tin was to serve as a flux for copper. He rightly points out that copper by itself would have been nearly infusible; and that the tin by itself would have been weak, soft, and comparatively useless. When, however, a small portion of tin was added to the copper, the bronze resulting from the admixture was hard enough to be formed into tools and weapons of various kinds, and to make, in short, the implements for which iron was afterwards used. But there is no proof forthcoming that this discovery in the fusing of metals was made in England in early days; on the contrary, Cæsar tells us that the bronze used by the natives of Britain was imported. It is difficult, however, to avoid believing that the Romans, at all events during the latter period of their occupation, mingled these metals into a valuable alloy in Britain itself, rather than exporting both of them for that process to be consummated farther south and then returned to our shores. We shall be able shortly to quote interesting and very recent evidence as to RomanoBritish mingling of copper and lead.

British tin being of such world-wide celebrity would be the first mineral to attract the attention of Roman mining enterprise, and we should have thought the last to provoke their skill in metallurgical operations. With regard to the Romans and the working of tin, it is, however, only right to give the decided and adverse opinion of my friend Mr. Haverfield, with whose knowledge of RomanoBritish subjects I do not for a moment feel that I can compete; though in this case I do not find myself entirely in accord. Mr. Haverfield in a communication made this year to the Antiquary, says :- "Writers on Roman Britain commonly assert that the most important mineral product of our island in Roman times was tin, but the assertion is a complete mistake. All our evidence goes to show that the tin trade of Cornwall died down about the Christian era, was not revived till the fourth century, and even then did not flourish very vigorously. If we ask what mineral

$$
{ }^{2} \text { Hist. Nat., xxxiv., 16, 4i. }
$$


was really abundant in Roman Britain, and what attracted Roman notice most, we must substitute lead for tin in our answer."

Second only to tin in importance, and of far greater archæological interest, owing to its much wider diffusion, comes lead. Before considering it in detail it may be well to offer a brief observation or two on Roman mining in general, and particularly with reference to the mining for lead. The operations of the miners under the Romans seem to "have been in" general similar to those which are still in use, but of course without the facilities that more recent discoveries and a greater knowledge of mechanics have brought into play. There is a good deal of evidence to be gleaned from contemporary writers as to the manner of their mining in Spain, whilst the researches of archæologists and the accidental discoveries of modern miners have yielded plain evidence of the work in Britain. The ore was first obtained near the surface, and the workings were abandoned as soon as their depth or the rise of unmanageable water rendered them unprofitable. Machinery was used to drain the mines. Diodorus and Strabo both make mention of Egyptian screws as employed for this purpose. By the Egyptian screw or pump is evidently meant the ingenious instrument known as the Screw of Archimedes. A remarkable discovery was made a few years ago in the ancient mines of Tharsis, near Huelva, in Spain, of an old Roman water-wheel, with fragments of the ropes still hanging to it by which the slaves kept it in continuous motion. ${ }^{1}$ Pliny writing before A.D. 79 (when he died), tells us that lead was obtained both in Spain and Gaul from deep and laborious mines, but that in Britain it was found near the surface so abundantly as to suggest a law to check its production beyond a certain quantity. ${ }^{2}$ This is a curious exemplification of early mining economics, and proves that the miners of to-day are not original in their endeavours to limit the out-put.

The surface lead veins in Britain of which Pliny speaks would be in four great districts. The first was in the

- See Archalogia Elliana, rol. vii., p. 280, where an illustration is given of this ancient wheel.
${ }^{2}$ Hist. Nat., xxxiv., 17, 49, "In Britannia sumino terræ corio adeo large, ut lex ultro dicatur, ne plus certo modo fiat." 
south on the Mendips, abore Cheddar, where the Roman Government had miners at work within six years of the landing of the Claudian legions.

The second was in the west, in the district of Ceangi, lying near the modern Flint, where lead mining was conducted by the government in or before the reign of Vespasian. In the reign of Domitian a barge containing a cargo of twenty lead pigs was wrecked in the Mersey, which was probably on its way to Chester or the interior of Britain. ${ }^{2}$

The third of these districts, and perhaps the most prolific, was in Derbyshire, the district of Lutudorum, which I can claim to have satisfactorily identified with Wirksworth, and not with Chesterfield as used to be contended. This district was being actively worked during the time of Hadrian. ${ }^{3}$. This surface working explains why so few ancient mining instruments have ever been found in the chief lead-bearing districts of Britain. The lead ore was probably collected from the surface by the aid of water artificially directed. The process, says Dr. Phillips, " is described by Pliny in terms so exactly applicable to the modern 'hushes' of Swaledale, that no doubt can remain of this custom, which is now esteemed rude and semi-barbarous, being of Roman or earlier date in Britain."

The fourth of Pliny's districts would be the important group of Shropshire lead-producing mountains known as the Stiperstones and its dependents, particularly Shelve Hill. Here Mr. Wright made most careful investigations, with the result that he found eight or nine parallel veins coming out on the surface of the rock, all of which had been worked by the Romans, beginning apparently from the bottom of the hill, and following the vein in the rock as far as they could trace it. The remains of their labour

1 In the Transactions of the Cardiff Naturalists' Society, for 1875 (pp. 1-5) is an interesting and well illustrated account by Mr. Waldron of Roman fibulæ and other ornaments of bronze, as well as glass and earthenware articles that he found at Charter House, on the Mendips range, about two miles from the Cheddar cliffs. These were discovered in 1873, when a company of mining adventurers were engaged in collecting and re-smelting for lead the slag and cinders left there by the Romans during their occupation of Britain. Ihis article is of much value in connection with Roman mining operations. IIy attention was not drawn to it until after the address was delivered.-J.C.C.

2 Camden's Britannia (ed. 1607), pr. 168,463 .

3 Antiquary, vol. xxix., p. 222. 
are visible along the whole surface of the hill, like irregular cuttings along a large cheese. These Shropshire mines, which were extensively worked at the beginning of the second century, ${ }^{1}$ afford interesting evidence as to how the Roman lead miners were gradually led on to deeper and more laborious undertakings. At the foot of Shelve Hill the veins of ore have been followed up in narrow cuitings, sometimes to a very considerable depth. In one instance a cutting is actually $120 \mathrm{ft}$. deep, and yet not wide enough at the bottom for more than one man to work in it. In other places where the vein of ore was wider and more massive, the Romans hollowed out caverns like chambers from which galleries ran in various directions. In one instance the vein has been followed down by a square ${ }^{2}$ shaft of great depth but of small dimensions, various other shafts and galleries of undoubted Roman origin have been found in different parts of these Shropshire mountains. ${ }^{3}$ It is in these deep workings that the few mining implements of Roman days hare been found. Two mining spades of cleft oak were found at Shelve Hill in the works of the "Roman Gravel Lead Mining Company," and were exhibited in the special museum formed at Shrewsbury in 1855 on the occasion of the meeting of the Institute.

Broadly speaking all mines under Imperial Rome were the property of the State. They were either left by the government in its own hauds and worked without any middleman, or were less frequently let or leased to individuals for a royalty or rent. In the former case they would be worked under the immediate supervision of some imperial official, who would be empowered to stamp the moulds with his master's name. In most of the British lead districts it is known that this was the case from the numerous pigs of lead that have been found stamped with the names of successive emperors. But in the Derbyshire or Wirksworth district three out of the five inscribed pigs bear private names. Two names thus found last century were L. Aruconius Verecundus

\footnotetext{
1 All the Shropshire pigs of lead bear the Emperor Hadrian's mark (A.D. 117-138).

The Romans preferred square shafts. The sereral well shafts recently exposed
}

at Silchester are all square.

${ }^{3} \mathrm{Mr}$. Wright published a full and most interesting account of the Roman lead mines at Shelve in the Illustrated London News of Oct. 4th, 1856. 
and C. Julius Protus. To these may be added the name of Publius Rubrius Abascantus on a beautifully lettered pig found in Derbyshire, near Wirksworth, on March 24th, 1894, and which I had the honour to exhibit before the Society of Antiquaries on May 10th. These men must have been lessees, who hired the workings from the imperial treasury.

Mr. Haverfield thinks that this appearance of the name of lessees only in Derbyshire, callsfor some special explanation, and is perhaps identified with certain laws or customs peculiar to the district. In this connection it is not a little remarkable to note that the Derbyshire lead-mining laws have always differed from those of other parts of the country, and do so to the present day. A formal inquiry was held as to their ancient customs as early as the reign of Edward I. The principal tract containing lead is still called the King's Field, and is co-extensive with the wapentake of Wirksworth, which was the district of Lutudensian metal worked by the Romans. It also includes a part of the High Peak. The mineral duties of the King's Field have been from time immemorial let on lease by the crown, part of the Oremaster's duty being to superintend the measurement of the ore and to receive the dues of the lessee of the crown. A perfect list of the crown lessees of the Wirksworth or main portion of the King's Field, has been drawn up from the timeof Edward IV.

Between thirty and forty years ago, Mr. Albert Way drew up a list of Roman inscribed pigs found in England, which he supplemented a few years later, arranging them in order of date under their respective emperors. About the same time Mr. Yates, working independently, produced for the Somersetshire Archæological Society a like list classified according to counties. I have gone carefully through both these lists, have corrected them in some small particulars, and have brought them up to date with a few additions. The following is the result, given in the briefest form, of the distribution and date of these Romano-British leaden pigs:-Cheshire, 22 ; Sussex, 6 ; Derbyshire, 5 ; Shropshire, 5 ; Somerset, 4 ; Norfolk, 3 (inscriptions not known); Yorkshire, 2; Hampshire, Nottinghamshire, and Staffordshire, 1 each. This gives a total of 50 , but it must be remembered that the large 
number mentioned under Cheshire include the twenty wrecked in the Mersey, named by Camden, which were divided between the Emperors Vespasian and Domitian. If we arrange them according to date, we find the following result with regard to 45 of the 50 . Britannicus (Tiberius Claudius), A.D. 44-48, one; Claudius, A.D. 41-54, six ; Nero, A.D. 54-68, one; Vespasian, A.D. 69-79, fifteen : Domitian, A.D. 81-96, fourteen ; Hadrian, A.D. 117-138; Antoninus Pius, A.D. 138-161; Antoninus and Verus, A.D. 163-169, one. From this it appears that these most striking evidences of Rome's working of Britain's lead all pertain to the earlier period of the Roman occupation. Some have deduced from this fact that the trade and working in lead fell away considerably after the time of Hadrian; but there is really no proof of this. A considerable number of pigs of lead of undoubted Roman smelting have been found from time to time uninscribed. As I write (July 15) news reaches me of one of this character just discovered at Bradwell, in Derbyshire. It is quite possible that the custom of lettering the pigs died out as time went on, and the country was more secure. Moreover, from the curious position in which some of these pigs have been found (particularly in Derbyshire), with heavy stones on the top of them, reversed, and near the surface, it seems likely that they were hidden away with fraudulent intent by workpeople or others, and afterwards lost sight of ; and if this suggestion is correct, it is some proof of the unsettled condition of things in the earlier days of the occupation. Later on there would not be near so much opportunity for this intentional mislaying, and therefore all the less probability of finding pigs of a later date. At all events we know that the Romans continued to use lead largely to the end of their stay in these islands, and therefore they must have continued their mining operations at least for provincial use, if not for exportation.

The place where the beautifully-lettered pig face downwards was found near Wirksworth last Easter Eve was carefully examined.

The adjacent ground had been here and there scooped out into hollows. Fires had evidently been made in these hollows, and the lead smelted in them on the spot and poured into the mould. Various fragments of lead ore still 
remained near the surface. These pigs would be cast wherever a sufficiency of surface lead could be found, and would be then left on the spot till they could be collected and taken away. In digging over the ground several curious branch-like pieces of thin rounded lead were found. These proved to be casts of fern roots. The molten lead when being smelted on the ground had burnt out the roots and thus left exact lead casts of their dimensions. The form of rude hearth-furnace that was used throughout the Wirksworth district till about 1720 (when the cupola began to succeed it) was probably identical with the means resorted to by the Romans. The Derbyshire hearth-furnace consisted of large rough stones, placed in the ground so as to form an oblong cavity, varying from one to two feet in width and depth, and from six to fourteen feet in length. Into this cavity the fuel and ore were put in alternate layers, the heat being raised by a large pair of bellows which were sometimes worked by a water-wheel. The fuel used was generally a mixture of wood and coal. As for bellows, we need not imagine that the Romans were not thoroughly habituated to their use; they were known at least a thousand years before Pliny. ${ }^{1}$ This crude form of smelting left much metal in the slag, and the refuse heaps of the Roman miners of Derbyshire have yielded from time to time most excellent lead when re-smelted.

Some thirty years ago when studying the old parish registers of Ashover, Derbyshire, I was surprised to read the following entry:-_ “ 1660 . Dorothy Matly, supposed wife of John Flint, of this parish, foreswore herselfe: whereon the ground open and she sanke over hed March 1st: and being found dead she was buried March 2nd." The explanation of this I curiously enough subsequently found in a rare tract of John Bunyan, called "The Life and Death of Mr. Badman," tirst published in 1680. He therein relates at length the story of Dorothy Matly, describing how she was engaged with many others in washing the rubbish from the old (Roman) lead mines,

\footnotetext{
${ }^{1}$ During excavations in Anglesea by Hon. W. O. Stanley, discovery was made of the vitrified nozzle of a bellows used for smelting purposes by the ancient Britcns (Arch. Journal, rol.
}

xxvii., pl. 4). Artificial reservoirs have been discorered near Roman smelting furnaces in the Forest of Dean, which are supposed to have been used for the moring of bellows by water-power. 
when she forswore herself, hoping that the earth would swallow her up if she had stolen the pence of which she was accused. The earth at that moment opened, she was buried to a depth of nine feet, and when the body was recovered, the pence was found in her clenched fist. I briefly allude to this story as the earliest instance $I$ have met with of the trade of re-using the Roman slag of the Derbyshire lead mines.

The remarkable way in which mining customs have continued in this island for sometbing like 1,000 years is further testified by the weight of these pigs. The modern pig of lead is about 1-16th of a fodder, or $176 \frac{1}{4} \mathrm{lbs}$. The three Roman pigs found in Derbyshire last century weighed respectively $173 \mathrm{lbs}$, $127 \mathrm{lbs}$., and $83 \mathrm{lbs}$.; whilst the one discovered this spring was still nearer to the standard, viz., 175 lbs. A pig from the Wirksworth district, found in Derbyshire, weighed something over $180 \mathrm{lbs}$. In fact the average weight of all the discovered Roman pigs closely approximates to $176 \mathrm{lbs}$. The fodder of lead varies somewhat in different counties. In Saxon or early Norman times we know from Domesday that the Derbyshire planstrata or cartload consisted of ten tabula or pigs. The word fodder, or fudur, both in Saxon and German, signifies a cartload.

The Romans used the British lead for coffins and sepulchral cists, which they often ornamented with graceful and striking patterns. There are excellent examples in the British Museum and in the York Museum.' There is also one in the Maidstone Museum, which was found at Plumstead, in Kent. They have likewise been found in Wilts, Essex, and Gloucestershire. A good many examples have been discovered in Normandy, and French archæologists are agreed that they are made from English lead. In Rome an immense quantity of early lead piping has been found, most of which probably came from Britain. The pipes were made of strips of cast lead bent round a rod and then soldered. Lead water pipes of Roman make are frequently found in England, as at Colchester, in Hadrian's Wall. At Bath there is a water channel $1 \mathrm{ft} .9 \mathrm{in}$. by 7 in. of lead nearly one inch in thickness. It was used for the lining of baths and cisterns. Sheets of lead $10 \mathrm{ft}$. long lined the basin of the great bath at Bath, weighing 30 lbs. to the 
foot. It was also largely used by the Romans for roofing purposes. Small pieces of sheet lead pierced with nail holes have recently been found at Silchester. Occasionally, too, lead was used by the Romans for smaller and ornamental purposes. The refuse of the Mendip mines have yielded Roman lamps and other small articles of lead. The British Museum possesses a beautiful vase five inches high, ornamented with figures and emblems, and encircled with a belt of glass jewels, which is made of lead, and evidently from the subject of the decorations intended for a wine cup.

With regard to silver, mention must briefly be made of the well-known ingot of Roman silver preserved in the British Museum. It was found in 1777, within the Tower of London, at a great depth, with three gold coins of Arcadius and Honorius. It weighs 320 grammes, and is fully described in vol. V. of the Archoologia. The British Museum also possesses the silver ingots found near Coleraine, in Ireland, with a large hoard of silver Roman coins. The lead ore of this country has always an alloy of silver, and the Romans we know extracted it with great care, as is proved by the term EXARG on some of the Derbyshire lead pigs, testifying that the silver had been extracted. doubtless in accordance with the process detailed by Pliny.

As to the most precious of metals, there seem good reasons for believing that the ancient gold mine of Gogofau, near Llan-Pumpsant, in Carmarthenshire, as well as other Welsh mines that occasionally produced the like precious ore, were worked by the Romans.

Pliny gives us in full the three processes that were then known to the Romans for the obtaining of gold. There is no doubt whatever, although the precise localities may not be known, that the imperial exchequer of Rome was enriched by the proceeds of the gold and silver mines of Britain. $^{1}$

The rude cake of copper found last century at Caerhen (the ancient Conarium), four miles from Conway, is still at Mostyn. It weighs $42 \mathrm{lbs}$, is $11 \mathrm{in}$. in diameter, and is stamped deeply on the upper surface with the words "Socio Romæ," and in smaller letters Nat. Sol., supposed

\footnotetext{
1 "Fert Britannia aurum et argentum Tacitus, Agricola, cap, zii. et alia metalla, pretium victoriae,"
} 
to stand for natale solum. The late Mr. Wright produced abundant proof that the Romans had worked copper in various parts of Montgomeryshire and Denbighshire, and particularly at Llanymynech Hill, on the northern borders of Shropshire and Montgomeryshire. The Romans also worked copper in the Island of Anglesea. In the account of the excavations on the site of the Roman city of Silchester during 1893 by Messrs. Hope and Fox, just issued in the current number of Archoologia, there occurs a record of much interest with regard to our present investigation. Among the objects found in house Number 4, of Insula VIII., were pieces of metallic residue composed chiefly of lead and copper. In two chambers of this small house were the remains of the flue of some furnaces, which could not in any way be taken as forming part of a hypocaust, so that the supposition seems reasonable as to the house having been once occupied by a worker in metals. Prof. Roberts-Austen, C.B., of the Mint, analysed specimens of this Silchester residue. He pronounced one of the specimens to be metallic lead containing five ounces of silver to the ton, and considered it to be lead obtained by the direct smelting of lead ores, and that the metallic lead had not been desilverized. A second specimen was of considerable interest, for it was a product of smelting lead and copper ores. The metallic portion contained 67.64 per cent. of copper and 12.42 per cent. of lead. The amount of silver was no less than 45.87 ounces to the ton of the material. The mass, according to Professor Roberts-Austen, was probably obtained by smelting complex argentiferous lead and copper ore, but it may have been the result of melting together argentiferous lead and argentiferous copper with a view to desilverize the copper. Cakes or discs of such an alloy would be placed on a sloping hearth and heated to a temperature well above the melting point of lead, with a view to sweat out the lead from the copper, which could be left behind as a sponge. The lead would carry away the silver it originally contained, as well as any silver present in the copper. Elaborate accounts of this process were published in the sixteenth century, but it is interesting to find indications of its use in later Roman times, and the specimens certainly point to the possession 
of considerable metallurgical knowledge by those who conducted the smelting operations which yielded these products.

The working of iron by the Romans was carried on after a most extensive fashion. In the operations connected with the mining and working of tin, lead, silver, gold, and copper, as we have just seen, there was considerable similarity between the methods then adopted and those that prevailed almost, if not down to our own times. But with regard to iron, the reverse is the case. The kinds of ore which the Romans used, as well as the smelting operations in iron, were completely different to and much more primitive than those now in vogue. The extensive strata of clay iron-stone of our carboniferous series were untouched by the Romans. The kinds of ore that they for the most part used were those which readily attract the attention of primitive people, and that lie near to or on the surface of the ground, such as hematite, nodules, and bog iron-ore, which are found among rocks of a comparatively recent geographical epoch. Our furnaces, too, are constructed on totally diflerent principles. In the neighbourhood of Habitancum and Lanchester, near Hadrian's Wall, masses of iron slag, or scoriæ, were found on the enclosure of Lanchester common; two large heaps were removed for the purpose of road-making, one consisting of 400 and the other of 600 cartloads of dross. During the operation of bringing this common into cultivation, the method adopted by the Romans of producing the blast necessary to smelt the metal was made apparent. "Two tunnels had been formed in the side of the hill: they were wide at one extremity, but tapered off to a narrow bore at the other, where they met in a point. 'The mouths of the channels opened towards the west, from which quarter a prevalent wind blows in this valley, and sometimes with great violence. The blast received by them would, when the wind was high, be poured with considerable force and effect upon the smelting furnaces at the extremity of the tunnels."

Roman coins have been found under the refuse of hematite mines at Luxborough, on the Brendon Hills, near Minehead, and also amid similar workings at Luccombe on the

${ }^{1}$ Dr. Bruce's The Roman Wall, pp. 432-4. 
confines of Exmoor, and in other parts of West Somersetshire. Roman pottery has turned up with frequency near Devizes, among the scoriæ of ancient iron works. In various places in Sussex, as in the parishes of Maresfield, Sedlescombe, and Westfield, immense masses of scorix or iron cinders have been found, in some places twenty feet thick. There can be no doubt whatever as to the date of these heaps, for they were besprinkled with fragments of Roman pottery and occasional coins. The Romans in this district dug small pits from which they extracted the iron nodules, which were then carried to the adjacent furnaces. These smelting furnaces seem always to have been placed on the slope of a hill, near the bottom, to facilitate the running out of the molten metal. The iron ore was broken up and placed in alternate layers with charcoal, some limestone being added as a flux. The mass was then surrounded and covered with a wall of clay, having holes at the bottom for letting in the draught and letting out the metal.

It is, however, throughout the Forest of Dean, in Gloucestershire, and its confines, that the Roman cinders abounded, and in such extraordinary profusion. As early as the middle of the seventeenth century, and throughout the eighteenth, it was the custom to commit these scoriæ to the furnace for the second time, so careless had been the Roman methods. Even at the close of the seventeenth century, when very little attention was paid to the Roman occupation of Britain, the Gloucestershire cinder district attracted considerable attention. Mr. Yarranton, in a book entitled Improvement by Sea and Land, which was published in 1698, says :- "It is evident that iron was in England a thousand years ago, by those great heap of cinders formerly made of ironstone, they being the offal or waste thrown out of the footblasts by the Romans; they then having no works to go by water to drive bellows, but all by the footblast, and at present great oaks are growing upon the tops of these cinder heaps, and monies continually is found amongst these cinders; but such as is found is all of the Roman coin ; most of which monies is copper; very little found of late days that is silcer: and this offal of the footblast by the Romans, then cast by, doth at present make the 
best and most profitable iron in England, it being mixed with some ironstone of the Forest of Dean : and there hath been and still is vast quantities of this sort of iron cinders in the counties of Monmouth, Hereford, and Gloucester ; and Mr. Yarranton found a vast quantity of Roman cinders near the walls of the city of Worcester, from whence he and others carried away many thousand tons of loads up the river Severn unto their iron furnaces, to be melted down into iron, with a mixture of the Forest of Dean ironstone; and within a hundred yards of the walls of the city of Worcester there was dug up one of the hearths of the Roman footblasts; it being then firm and in order, and was $7 \mathrm{ft}$. deep in the earth; and by the side of the work there was found out a pot of Roman wine, to the quantity of a peck, some of which was presented to Sir Dugdale, and part thereof is now in the king's closet; by all which circumstances it clearly appears that the Romans made iron in England, and so far up the river Severn as the city of Worcester, where as yet there are vast quantities remaining."

A quaint legend is given in the life of St. Egwin, which strikingly illustrates the extent of the iron trade in that district, as it represents the town of Alcester (the Roman Alauria), which is situated on the Worcestershire borders of the county of Warwick, as inhabited exclusively by smiths and filled with smithies. When the saint went to convert these pagans to Christianity, no sooner did he begin to preach than they all began to beat with their hammers on the anvils, producing such a frightful din that he might as well have preached to the tempest. St. Egwin, indignant at the reception thus given to divine iruths, raised his hands to heaven and invoked a curse on the townfolk and their occupation. Instantly the town was swallowed up by an earthquake, and henceforth no one was able successfully or protitably to carry on the trade of a smith in that locality. ${ }^{\prime}$ It is interesting, in connection with the extent of the Roman ironworks in Britain, to note the remarkable proofs of the extraordinary and varied skill of the Romans when amongst us in the construction of peaceful implements and tools of iron that have come to light during recent years, and which seem

\footnotetext{
'Capgrare's Nota Legenda Anglia.
} 
to belong to the latter period of their occupation. A hoard of no less than 96 iron articles was discovered at Great Chesterford, Essex, in 1854, and was fully described in the Journal of the Institute. ${ }^{1}$ In 1890 a most remarkable hoard of iron implements was found at Silchester, which included anvils of three kinds, axes and adzes, hammers, tongs, chisels, gouges, plough-coulters, a file, a plane, a horseshoe, a lamp, and a large gridiron. These are fully described and illustrated by Sir John Evans. K.C.B., in the current number of the Archoologia issued to the Fellows within the last few days. ${ }^{2}$

Though not technically a mineral, a few words must be said in conclusion with regard to that carboniferous fossil coal. Dr., Bruce tells us that in nearly all the stations on the line of the great Roman wall coal has been found. In several places the source whence the fuel was obtained can be pointed out, and there were extensive early workings in the neighbourhood of Grindon Lake, near Sewing Shields. Nor can there be any doubt that they discovered the Shropshire coalfield, for coal has been found in abundance both unburnt and in cinders on the site of Uriconium. $^{3}$ I have myself found coal cinders in lead scoriæ in Derbyshire, near Wirksworth, that appeared to date back to Roman days. There does not appear, however, to have been more than an occasional and comparatively limited use of this fuel by the Romans, and but. rarely for smelting purposes. There was no deep coal mining; only that which cropped out at the surface was used or followed up for a comparatively short distance. The great abundance of wood forbad any special expenditure of energy in that direction. So little was coal known to or used by the Romans that they had not even any proper designation of their own for a substance found in so many parts of their extensive Empire.

To many of us-particularly to one like myself, who was for many years a colliery proprietor before taking Holy Orders, and who remains intensely interested in the condition of the mining population and their honourable

\footnotetext{
1 Arch. Journal, vol. xiii., p. 1.

2 Archaologia, vol. liv, pp. 139-156.

3 Wright's Celt, Roman, and Saxon, p. 290. This use of coal in the hypocausts of Wroxeter accounts, in Mr.
}

Fox's opinion, for their greater eleration and somewhat different construction as compared with the hypocausts of Silchester and other Romano-Britisl. stations. 
attempts to keep abreast of the times in which they liveone of the most interesting inquiries in connection with the mining of the past is the lot of those who laboured in the early mines of Britain. As to this, it does not appear possible to speak with any absolute certainty. Dr. Phillips draws a somewhat captivating but, we fear, imaginary picture of "the politic lords of the world who broke up no national industry, and set no legionaries to supplant the native miners; but stationing a few cohorts on the ancient roads, in or close to the mining districts, to control a rude population, received regularly the fruits of the industry which they might direct, but did not personally share. Viewed in this light, how complete appears the grasp of the Roman treasury on the mining fields of Britain!"

But the true picture, we fear, is a much blacker one than this. In Tacitus' Life of Agricola a speech is attributed to the British leader, Galgacus, wherein servitude in the mines is specially mentioned as the consequence of defeat. This slavery, as we learn from Diodorus, was exceedingly severe. The consideration then of the mining operations of the Romans corrects more than one popular but mistaken view as to their occupation of Britain. Instead of remote and mountainous parts of the land, such as the Peak of Derbyshire or the Shropshire borders of Wales, being the districts wherein the Britons continued to maintain their independence, it is just in these very territories in consequence of their mineral wealth, that the heel of the conqueror pressed the heaviest. It was in these parts that the troops were specially massed and the stations and camps were frequent, not to restrain an independent race of natives, but to overawe and keep in check a large population of slaves and condemned criminals, whose forced labour was used for the production of mineral wealth. ${ }^{1}$ Beneath all the civilization and engineering skill of mighty Rome, there was usually a fierce and sustained cruelty towards the people whom she subdued. This tyranny was probably nowhere so apparent as in the mining districts of Britain.

${ }^{1} \mathrm{~A}$ most interesting account of the sad treatment of Christian slaves and prisoners in the Roman mines of Palestine and Egypt is giren by Very Rer.

Father Hirst in his paper on "Mining Operations by the Ancient Romans" read at the Newcastle meeting (Arch.Jou;nal, vol. xlii., pp. 20-40). 